\title{
PKM-PEDULI PETERNAK BABI TERDAMPAK WABAH AFRICAN SWINE FEVER DAN PANDEMI COVID-19
}

\author{
Gerson Y. I. Sakan*, Yanse Yane Rumlaklak*, Ewaldus Wera* \\ * Program Studi Kesehatan Hewan Politeknik Pertanian Negeri Kupang \\ e-mail : gersonsakan8@gmail.com
}

\begin{abstract}
ABSTRAK
Kelompok Tani Sehati dan Kelompok Tani Syalom adalah dua dari kelompok tani ternak yang ada di Kelurahan Tuatuka, dengan berfokus pada usaha ternak babi dan sapi sebagai sumber mata pencaharian, selain bertani mengolah sawah. Selama menjadi kelompok tani ternak binaan Jurusan Peternakan Politani Kupang, usaha ternak babi dengan sistem pro-mitra yang dikembangkan berjalan dengan baik dan menguntungkan bagi peternak. Masuknya wabah penyakit demam babi Afrika (African swine fever/ASF) di Pulau Timor sejak akhir Tahun 2019 menjadi masalah besar bagi peternak babi. Penularan penyakit ini semakin meluas dan banyak ternak babi yang ditemukan mati dalam waktu singkat. Kerugian ekonomi akibat kematian ternak babi sudah tentu menjadi masalah utama bagi petani ternak, termasuk dalam Kelompok Tani Sehati dan Kelompok Tani Syalom. Ternak babi yang biasanya dijadikan tabungan untuk kebutuhan keluarga menjadi hilang seketika. Kondisi ini terus diperparah dengan adanya pandemi Covid-19, yang semakin menyulitkan perkonomian peternak. Kehadiran Program Studi Kesehatan Hewan Politani Negeri Kupang dalam memberikan sedikit kepedulian berupa pembagian bingkisan sembako bagi kedua kelompok ini dirasakan sangat bermanfaat. Selain itu, kegiatan penyuluhan peternakan dan kesehatan hewan serta pendampingan yang diberikan juga menjadi penyemangat tersendiri bagi kedua kelompok ini untuk terus melanjutkan usaha peternakan selain ternak babi sebagai peluang usaha baru dan menghasilkan, walaupun masih dalam suasana pandemi Covid-19.
\end{abstract}

Kata Kunci : African Swine Fever, Babi, Pandemi Covid-19, Peternak. 


\section{PENDAHULUAN}

Usaha peternakan babi untuk menghasilkan daging babi turut memegang peran penting dalam penyediaan protein hewani bagi masyarakat. Pemeliharaan ternak babi yang terus tersebar hampir di seluruh wilayah Timor Barat, sedikit memberi gambaran adanya peluang pengembangan sektor usaha peternakan babi di Provinsi NTT dengan baik. Berbagai upaya pendampingan dan penguatan bagi para peternak babi telah dilakukan oleh pemerintah melalui instansi terkait yang ada di setiap daerah. Kampus Politeknik Pertanian Negeri Kupang melalui Jurusan Peternakan sejak tahun 2018 lalu telah meluncurkan sistem Pro-Mitra yang sangat membantu bagi semua kelompok mitra peternak babi, terkhususnya yang ada di Kelurahan Tuatuka. Kerjasama ini dilakukan melalui bantuan modal usaha (bibit dan pakan ternak babi) serta pendampingan tim teknis untuk pemeliharaan dan juga penanganan kesehatan hewan selama dilakukanannya pemeliharaan ternak babi. Kelompok Tani Sehati dan Kelompok Tani Syalom adalah dua kelompok ternak babi binaan Jurusan Peternakan Politani Negeri Kupang yang sudah berhasil menerapkan sistem Pro-Mitra dan dirasakan manfaatnya bagi seluruh anggota kelompok ini karena apa yang dikembangkan berjalan dengan baik dan menguntungkan.

Masuknya wabah penyakit demam babi Afrika (African swine fever/ASF) di Pulau Timor sejak akhir Tahun 2019 menjadi masalah besar bagi peternak babi. Penularan penyakit ini semakin meluas dan banyak ternak babi yang ditemukan mati dalam waktu singkat. Kerugian ekonomi akibat kematian ternak babi sudah tentu menjadi masalah utama bagi petani ternak, termasuk dalam Kelompok Tani Sehati dan Kelompok Tani Syalom.

Jalur potensial masuknya ASF ke Indonesia khususnya di wilayah Timor Barat Provinsi NTT sejak akhir Tahun 2019 berasal dari Timor Leste, melalui beberapa aktivitas mobilitas darat, laut, dan udara. Mobilitas warga di sekitar perbatasan sangat tinggi mengingat hubungan kekerabatan yang erat antara warga Indonesia dan Timor Leste (Winarso et al., 2019).

Demam babi Afrika (African Swine Fever/ASF) adalah penyakit virus pada babi yang sangat menular dengan mortalitas mendekati $100 \%$, sehingga mengakibatkan kerugian ekonomi yang 
sangat besar (Sánchez-Cordón et al., 2018). Penyakit ini menyebar melalui kontak langsung dengan hewan terinfeksi atau karena makan sisa-sisa yang mengandung daging babi atau produk daging babi yang tak diproses. Babi yang sembuh dari infeksi dapat membawa virus selama beberapa bulan di tubuhnya. Virus sangat stabil dalam produk daging dan lingkungan. Meski telah melalui pengolahan, pengemasan, dan pengangkutan, produk daging yang terkontaminasi pada sumbernya dapat tetap mampu menyebarkan penyakit. Lalat, caplak, dan insekta lain juga dapat menyebarkan virus antar-babi, begitu juga bangunan kandang, kendaraan, alat, atau pakaian yang terkontaminasi. Pembersihan secara reguler kandang babi, peralatan, alat angkut, dan fasilitas lain tak mampu membunuh virus. Virus dapat bertahan pada temperatur sangat rendah. Resistensi virus yang tinggi dan belum adanya vaksin membuat pengendalian ASF menjadi sangat sulit (Naipospos, 2019a).

Virus ASF memiliki dampak sosio-ekonomi yang cukup serius di negara-negara yang terinfeksi virus ini. Transmisi dan penyebaran Epidemiologi dari demam babi afrika cukup kompleks dan bervariasi. Hal ini bergantung pada kondisi lingkungan, keberadaan vektor, tingkah laku manusia, dan keberadaan babi liar. Alur transmisi dapat melalui beberapa cara, yaitu: Kontak langsung dengan babi yang terinfeksi oleh virus ASF Kontak tidak langsung melalui pengonsumsian daging atau produk daging olahan dari hewan yang terinfeksi, termasuk sisa bahan makanan, pakan, babi hidup dan babi liar yang terinfeksi maupun kendaraan dan sepatu yang terkontaminasi (Penrith, 2009; Sánchez-Cordón et al., 2018; Naipospos, 2019b).

Gejala-gejala klinis dan tingkat kematian bergantung pada jenis virulensi virus dan spesies babi. Berikut adalah beberapa jenis gejala klinis pada bentuk-bentuk virus ASF: Gejala akut dari ASF ditandai dengan demam tinggi, depresi, anoreksia, kehilangan selera makan, pendarahan pada kulit (kemerahan pada kulit telinga, perut, dan kaki), keguguran pada induk yang hamil, sianosis, muntah, diare, dan kematian dalam waktu 2-10 hari (FAO, 2009). Tingkat kematian pada bentuk ini dapat mencapai 90\% atau lebih (Chenais et al., 2019). Gejala sub akut dan kronik ASF disebabkan oleh virus dengan virulensi moderat atau rendah. Jenis virus ini menghasilkan gejalagejala klinis yang tidak begitu jelas dan dapat terlihat dalam periode waktu yang lebih lama. Tingkat kematian jenis virus ini lebih rendah, yaitu berkisar antara 30-70\%. Gejala penyakit kronik 
termasuk penurunan berat badan, demam yang berselang, gejala pernafasan, penyakit kulit kronis, dan radang sendi. Pencegahan dan pengawasan Pencegahan di negara-negara yang belum terinfeksi dapat dilakukan dengan memperketat kebijakan impor dan pengukuran biosekuritas (Naipospos, 2019b).

Wabah ASF akan sangat berdampak terutama pada peternakan rakyat di Negara berkembang yang memelihara babi secara tradisional dan sebagai penghasilan tambahan (Sánchez-Cordón et al., 2018). Kondisi peternak babi di Kelurahan Tuatuka, yang sebagian besar memelihara ternak babi secara semi intensif dengan penerapan biosekuriti yang rendah ikut memberi peluang masuknya wabah penyakit ASF ini. Sebagian besar peternak mengalami kerugian ekonomi akibat kematian ternak babi. Ternak babi yang umumnya menjadi harapan tabungan keluarga dikala susah hilang seketika. Rendahnya pemahaman tentang penyakit ini dan cara pencegahannya yang turut mendukung penyebaran penyakit ini semakin meluas dan menimbulkan banyak kematian ternak babi. Situasi ini semakin dipersulit dengan munculnya Pandemi Covid-19 yang mengancam kesehatan dan keselamatan warga di seluruh dunia, dan secara ekonomi mempengaruhi berbagai usaha peternakan termasuk kelompok petani ternak babi.

Pandemi Covid-19 menimbulkan berbagai permasalahan dalam industri peternakan. Covid-19 menyebabkan krisis dan kerawanan pangan akut di Somalia, Afganistan dan Afrika Timur. Gangguan tranportasi dan penurunan harga produk pangan di Bangladesh., kendala perdagangan bagi negara pengimpor makanan seperti Karibia, Ekuador, Venezuela. Covid-19 juga berdampak pada perekonomian domestik (Food and Agriculture Organization of the United Nations, 2020). Dampak tersebut berupa penurunan konsumsi dan daya beli, penurunan kinerja perusahaan, ancaman sektor perbankan dan keuangan. Covid-19 pada aspek konsumsi dan daya beli menyebabkan pengurangan jumlah tenaga kerja dan penurunan pendapatan (Pakpahan, 2020).

Kondisi yang cukup memprihatinkan ini terus dirasakan oleh para petani peternak babi. Ibaratnya seperti sudah jatuh dan malah tertimpa tangga. Munculnya virus ASF serta adanya pandemi Covid19 ini menjadi tantangan berat bagi para peternak babi agar dapat terus berjuang untuk dapat 
bertahan dan kembali mengusahakan ternak sebagai sumber pendapatan keluarga, walau disisi lain juga masih ditemukan adanya ketakutan bagi peternak babi untuk kembali memulai usaha.

Tujuan dilakukannya kegiatan pengabdian kepada masyarakat (PKM) ini adalah untuk mendampingi peternak babi terdampak wabah ASF dan Covid-19, agar kembali bangkit dan memulai usaha pemeliharaan ternak babi atau usaha ternak lainnya. Berhubung hingga saat ini belum ada vaksin atau obat untuk penyakit ASF maka melalui kegiatan penyuluhan, para peternak juga diedukasi akan manajemen pemeliharaan ternak babi dalam situasi wabah ASF dan juga diperkenalkan dengan berbagai prospek usaha peternakan selain ternak babi yang dapat berkembang baik walau dalam situasi pandemi Covid-19. Selain itu melalui kegiatan PKM ini juga dilakukan pemberian paket sembako kepada masing-masing anggota Kelompok Tani Sehati dan Kelompok Tani Syalom sebagai wujud kepedulian kampus Politeknik Pertanian Negeri Kupang melalui Program Studi Kesehatan Hewan kepada peternak.

\section{MASALAH}

Wabah penyakit ASF pada babi dirasakan cukup meresahkan para peternak babi di Kelurahan Tuatuka, terkhususnya pada Kelompok Tani Sehati dan Kelompok Tani Syalom. Dalam waktu singkat semua ternak babi yang menjadi tumpuan harapan dan tabungan keluarga harus mati siasia karena penyakit ini. Kondisi ini diawali dengan kurangnya pemahaman petani ternak akan apa itu penyakit ASF, bagaimana cara penularan dan pencegahan penyakit ini, sehingga ketika terjadi kasus penyakit ASF masuk ke lingkungan Kelurahan Tuatuka maka dengan mudanya menularkan ke seluruh peternak yang ada. Penanganan ternak mati yang tidak tepat maupun pemotongan hewan sakit diduga menjadi sumber penyebaran penyakit di lingkungan peternak yang berdekatan dengan Kelompok Tani Sehati dan Kelompok Tani Syalom. Para peternak merugi secara ekonomi karena modal pemeliharaan termasuk biaya pakan harus hilang begitu saja, sementara tuntutan pemenuhan kebutuhan pokok sehari-hari sudah ada didepan mata. Dengan mengalami kehilangan ternak babi, para petani peternak inipun akhirnya hanya mengandalkan usaha pertanian tanaman hortikulura sebagai sumber pendapatan mereka sehari-hari. 
Wabah Covid-19 yang terjadi di Indonesia memberikan dampak besar bagi semua sektor kehidupan terutama kesehatan dan ekonomi, termasuk di dalamnya usaha pertanian dan peternakan. Keadaan peternak babi yang sebelumnya sudah merugi akibat wabah penyakit ASF kini semakin diperparah dengan adanya pandemic Covid-19 yang mengharuskan para peternak untuk lebih banyak berdiam di rumah. Hasil jualan usaha pertanian tanaman hortikultura di pasar juga tidak memberi keuntungan yang berarti karena rendahnya daya beli masyarakat sehingga membuat para petani peternak ini semakin terdampak secara ekonomi karena menurunnya pendapatan keluarga ditengah wabah Covid-19 ini.

\section{METODE}

Beberapa metode yang digunakan dalam kaitan dengan pelaksanaan kegiatan PKM-Prodi Keswan Peduli peternak babi terdampak wabah African Swine Fever dan Pandemi Covid-19 adalah melalui bantuan langsung berupa pemberian bingkisan (sembako), bahan desinfektan untuk desinfeksi kandang babi maupun masker kain dan hand sanitiser kepada masing-masing peternak yang tergabung dalam Kelompok Tani Sehati dan Kelompok Tani Syalom dilanjutkan dengan serangkaian kegiatan penyuluhan peternakan dan kesehatan hewan.

Kegiatan PKM-Prodi Keswan Peduli peternak babi terdampak wabah ASF dan Pandemi Covid-19 ini dilaksanakan di Kelurahan Tuatuka pada hari Kamis tanggal 30 Juli 2020. Pemberian bantuan dan kegiatan edukasi difokuskan pada 2 kelompok tani yang menjadi Mitra binaan Jurusan Peternakan Politani Negeri Kupang yaitu Kelompok Tani Sehati dan Kelompok Tani Syaloom. Kedua Kelompok Tani merupakan contoh dari masyarakat peternak terdampak wabah ASF dan Pandemi Covid-19.

\section{HASIL YANG DICAPAI}

Pelaksanaan kegiatan PKM-Prodi Keswan Peduli peternak babi Terdampak wabah African Swine Fever dan Pandemi Covid-19 mendapat sambutan baik dari Masyarakat Kelurahan Tuatuka terkhususnya Kelompok Tani Sehati dan Kelompok Tani Syalom. Hal ini terlihat dari begitu 
antusiasnya anggota dari kedua kelompok ini yang hadir pada saat pembagian bingkisan dan pada saat berlangsungnya kegiatan penyuluhan peternakan dan kesehatan hewan. Pemberian sedikit bantuan kepada masing-masing angota kelompok ini berupa bingkisan (satu paket sembako), bahan desinfektan untuk desinfeksi kandang babi maupun masker kain dan hand sanitizer. Pemberian paket bantuan ini diserahkan langsung oleh Ketua Pusat Penelitian dan Pengabdian Masyarakat Politani Negeri Kupang dan juga Ketua Jurusan Peternakan, serta turut menyaksikan dalam penyerahan bantuan ini adalah Ibu Pendeta dan Tokoh Jemaat dari Gereja GMIT Glorya Tuatuka (Gambar 1).

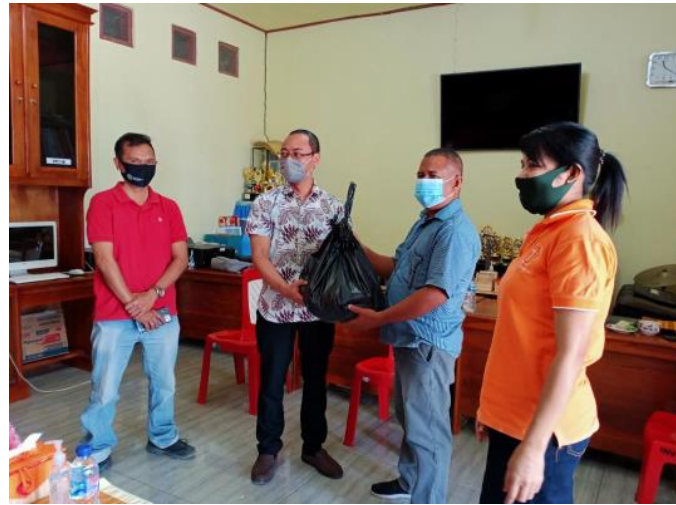

a

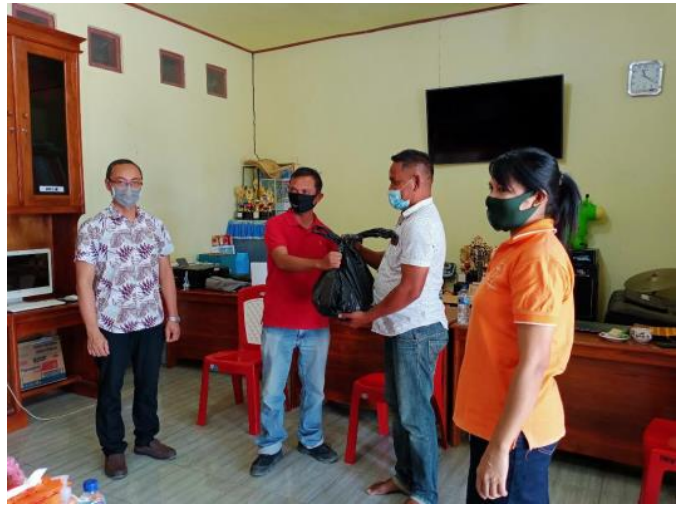

b

Gambar 1. Penyerahan paket bantuan kepada Perwakilan Kelompok Tani Sehati oleh Kepala P3M Politani Kupang (a) dan penyerahan paket bantuan kepada Perwakilan Kelompok Tani Syalom oleh Ketua Jurusan Peternakan Politani Kupang (b).

Fokus kegiatan PKM selanjutnya adalah mengajak semua anggota Kelompok Tani Sehati dan Kelompok Tani Syalom mengikuti penyuluhan yang disampaikan oleh para narasumber yang sangat berkompeten pada bidangnya. Pemberian materi penyuluhan tentang "Penyakit African Swine Fever (ASF) terkait Dampak dan Penanggulangan" dibawakan oleh Dr. Drh. IGK Oka Wirawan, MP, selanjutnya diikuti dengan materi penyuluhan tentang "Manajemen Perkandangan Ternak Sapi Potong” yang disampaikan oleh Ferdinan Suek, S.Pt., M.Si. Materi lain yang turut disampaikan adalah "Pengolahan Limbah Pertanian Sebagai Pakan Ternak Ruminansia" disampaikan oleh Aholiab Aoetpah, S.Pt., M.Rur.Sc., Ph.D (Gambar 2). 


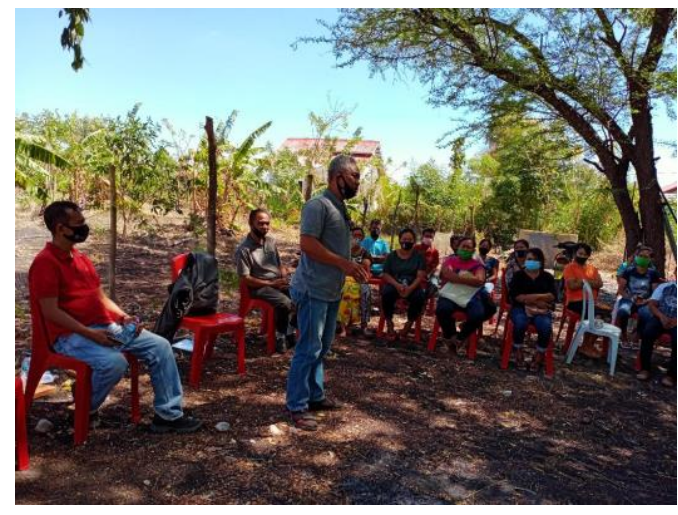

a

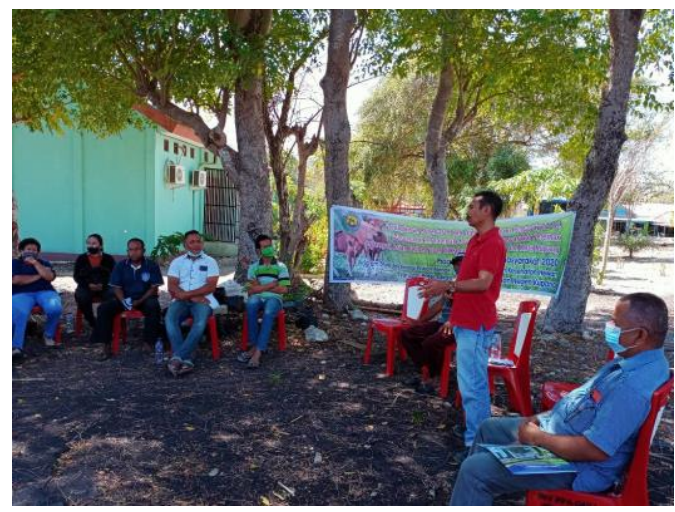

b

Gambar 2. Penyampaian materi penyuluhan dan diskusi berkaitan dengan penyakit ASF (a) dan penyampaian materi dan diskusi tentang pemeliharaan sapi potong serta pengolahan limbah pertanian sebagai pakan ternak ruminansia (b).

Pemilihan materi penyuluhan ini didasarkan pada situasi dan kebutuhan dari Kelompok Tani Sehati dan Kelompok Tani Syalom agar dapat memahami akan penyakit ASF dengan baik sehingga peternak dapat mengenali gejala penyakit, cara penularan penyakit ASF serta mampu untuk menerapkan langkah-langkah pencegahan yang benar ditingkat peternakan. Pada pemberian materi berkaitan dengan ASF ini, para peternak juga dibekali beberapa tips sederhana yang dapat dilakukan tatkala peternak ingin kembali memelihara ternak babi, termasuk didalamnya adalah pemilihan bibit dan penerapan sanitasi dan desinfeksi kandang secara teratur. Pemilihan kedua materi lainnya berkaitan dengan pemeliaraan sapi potong dimaksudkan untuk menjadi bekal bagi anggota Kelompok Tani Sehati dan Kelompok Tani Syalom yang sudah tidak lagi memelihara ternak babi agar dapat melirik ternak sapi potong sebagai peluang usaha yang bagus untuk dikembangkan di Kelurahan Tuatuka, mengingat potensi alam akan ketersediaan bahan pakan ternak yang sangat mendukung di wilayah ini.

Selama berlangsungnya kegiatan penyuluhan, masing-masing anggota kelompok ini juga cukup antusias dalam memberikan pertanyaan dan menyimak setiap materi diskusi yang ada. Dalam diskusi lanjutan tersebut, beberapa anggota kelompok juga berminat untuk melakukan usaha pemeliharaan ayam, terkhususnya ayam kampung super. Diskusi tentang usaha pemeliharaan ternak ayam kampung super, terkait prospek usaha ditengah Pandemi Covid-19 dan juga manajemen serta tata cara pemeliharaan yang benar pun dibahas secara baik oleh beberapa para 
peserta PKM dari Jurusan Peternakan yang berkompeten dalam bidang unggas. Diakhir dari sesi diskusi ini semua anggota kelompok juga diberikan motivasi oleh Ketua Jurusan Peternakan Politani Negeri Kupang agar tidak patah semangat dalam menghadapi wabah penyakit ASF terutama dalam situasi Pandemi Covid-19 saat ini, sehingga terus mengupayakan pemeliharaan ternak sebagai penopang ekonomi keluarga. Jurusan Peternakan Politani Negeri Kupang melalui ketiga program studi yang ada akan terus mendampingi Kelompok Tani Sehati dan Kelompok Tani Syalom dalam membangun kembali usaha peternakan babi maupun komoditi usaha peternakan lainnya.

\section{SIMPULAN DAN SARAN}

Berdasarkan hasil kegiatan PKM-Prodi Keswan Peduli peternak babi Terdampak wabah ASF dan Pandemi Covid-19, terkhususnya bagi anggota Kelompok Tani Sehati dan Kelompok Tani Syalom sangat dirasakan manfaatnya, karena bantuan yang diberikan dapat langsung meringankan sedikit beban mereka dalam memenuhi kebutuhan pokok sehari-hari. Pemberian masker dan hand sanitiser juga sangat membantu mereka tatkala harus beraktifitas di luar rumah dan harus menerapkan protocol kesehatan pencegahan Covid-19. Pelaksanaan kegiatan penyuluhan peternakan dan kesehatan hewan juga memberikan manfaat bagi para anggota kelompok tentang apa itu penyakit ASF agar selalu waspada dan menerapkan langkah-langkah pencegahan ASF jika ingin kembali beternak babi. Setelah terpuruk karena wabah ASF, melalui kegiatan penyuluhan ini para anggota kelompok ini juga kembali termotivasi untuk belajar beralih melakukan penggemukan ternak sapi potong dan pemeliharaa ayam kampung super sebagai alternative pilihan usaha yang menjanjikan pada masa Pandemi Covid-19. Sebagai salah satu saran rekomendasi untuk kegiatan PKM selanjutnya adalah mendampingi usaha penggemukan ternak sapi potong atau merintis kelompok usaha bersama untuk pemeliharaan ayam kampung super.

\section{DAFTAR PUSTAKA}

Chenais E., Depner K., Guberti V., Dietze K., Viltrop A and Stahl K. 2019. Epidemiological considerations on African swine fever in Europe 2014-2018. Porc Heal Manag. 5(1):1-10. 
Food and Agriculture Organization of the United Nations (FAO). 2009. African Swine Fever General Disease Information Sheets What is African swine fever? General Disease Information Sheets Where is the disease found? Anim Heal.: 1-6.

Food and Agriculture Organization of the United Nations (FAO). (2020). FAO needs \$350 million to avert rising hunger as countries reel from COVID-19 pandemic's impact, Diakses pada 18 September 2020 .

Naipospos, Tri Satya Putri. (2019a). Dampak Demam Babi Afrika. Center for Indonesian $\begin{array}{lllllll}\text { Veterinary } & \text { Analytical } & \text { Studies } & \text { (CIVAS). } & \text { Tanggal } 8 & \text { Oktober } & 2019 .\end{array}$ http://civas.net/2019/10/08/dampak-demam-babi-afrika/

Naipospos, Tri Satya Putri. (2019b). Opsi Pengendalian dan Manajemen Resiko African Swine Fever (ASF). Materi simulasi penyakit hewan eksotik African Swine Fever (ASF), Kuta-Bali 18 20 Desember 2019. https://www.slideshare.net/Naipospos/opsi-pengendalian-dan-manajemen$\underline{\text { risiko-african-swine-fever-denpasar-1820-desember-2019 }}$

Pakpahan, A. K. (2020). Covid-19 dan Implikasi Bagi Usaha Mikro, Kecil dan Menengah. Jurnal Ilmiah Hubungan Internasional hal 1-6.

Penrith, Mary Louise. (2009). African Swine Fever. Onderstepoort Journal of Veterinary Research, $76: 91-95$.

Sánchez-Cordón, P. J., M. Montoya, A. L. Reis, and L. K. Dixon. 2018. “African Swine Fever: A Re-Emerging Viral Disease Threatening the Global Pig. Industry." Veterinary Journal 233 (January): 41-48. https://doi.org/10.1016/j.tvj1.2017.12.025. 
Winarso, Aji., Hartanto, Nur., dan Rofi'ah, Siti. (2019). Ancaman African Swine Fever masuk ke wilayah Indonesia melalui Nusa Tenggara Timur. Prosiding Seminar Nasional VII Fakultas Kedokteran Hewan Universitas Nusa Cendana Swiss Bel-inn Kristal Kupang, 17 Oktober 2019 : 1 $-6$. 